\title{
Estimation of cytogenetic risk among coke oven workers exposed to polycyclic aromatic hydrocarbons
}

\author{
Shanmugam Sureshkumar ${ }^{\circledR}$, Vellingiri Balachandar ${ }^{1 凶}$, Subramaniam Mohana Devi ${ }^{1}$, \\ Meyyazhagan Arun', Alagamuthu Karthickkumar1, Balasubramanian Balamuralikrishnan', \\ Kathannan Sankar', Shafi Ahammed Khan Mustaqahamed1, Shanwaz N. Dharwadkar3, Kes- \\ havarao Sasikala' and Ssang-Goo Cho²
}

'Human Molecular Genetics Laboratory, Department of Zoology, School of Life Sciences, Bharathiar University, Coimbatore, Tamil Nadu, India; 2Molecular cell Biology and Stem Cell Laboratory, Department of Animal Biotechnology, Konkuk University, Hwayang-dong, Gwangjin-gu, Seoul, Korea; ${ }^{3}$ LLES S-Nijalingappa College, KLE Medical University, Bangalore, Karnataka, India

Polycyclic aromatic hydrocarbons (PAHs) result from the incomplete combustion of natural or synthetic organic materials. The working environment at a coke plant can negatively affect the employed workers who were exposed to coke oven emissions containing PAHs, which formed and released into the environment by the process of pyrolysis of coke. This study aims to analyze the relationship between the exposure of PAHs and the risk of genetic damages such as chromosomal alteration (CA), micronucleus (MN), and DNA damage (PCR-RFLP) in peripheral blood lymphocytes of 27 coke oven workers and equal number of control subjects. The exposed subjects and controls were divided into two groups based on their age (group $\mathrm{I}<35$ years and group II $\geq 35$ years). The exposed subjects were further classified into two groups based on the exposure period $(<12$ years and $\geq 12$ years). The frequencies of $C A$ and $M N$ in exposed subjects are relatively high with respect to controls. The XRCC1 $399 \mathrm{Arg} / \mathrm{gln}$ polymorphism showed a substantial smaller difference in allele frequencies between exposed and control subjects. Based on present data, it was concluded that coke oven workers under risk should be monitored for adverse effects of the any long-term exposure.

Key words: polycyclic aromatic hydrocarbons (PAHs), coke oven workers, chromosomal aberrations (CA), micronucleus (MN), XRCC1

Received: 28 June, 2012; revised: 24 July, 2013; accepted: 02 August, 2013; available on-line: 16 September, 2013

\section{INTRODUCTION}

Polycyclic aromatic hydrocarbons (PAHs) are well known, widely distributed carcinogenic compounds. Coke oven workers are frequently exposed to high concentrations of PAHs (Wu et al., 1998; Chen et al., 1999; Kuljukka-Rabb et al., 2002; IARC 2010), especially those working at the top sides of the ovens. An incomplete combustion of organic compounds in the environment was identified as a major source of carcinogenic risk. It constitutes a major part of air pollution in the coke oven area (IARC, 1987). PAHs have been identified as cancerinducing chemicals for humans (IARC, 1983; Yang et al, 2002) and the exposure to those compounds at the workplace has been analyzed by the increased levels of biomarker, such as peripheral blood lymphocyte culture (Hemminki et al., 1990; Bender et al., 1992; Clonfero et al., 1995). Epidemiological studies have associated a higher incidence of lung, scrotal, bladder, and skin cancer with occupational PAHs exposure (Dipple et al., 1984; IARC, 1984; Armstrong et al., 2004; Marczynski et al., 2005; Chen et al., 2007). Complex interactions between environmental and genetic factors are involved in the development of most of the human cancers (Perera, 1997). Besides bulky DNA adducts of carcinogenic PAHs, such as Benzo(a)pyrene diolepoxide (BPDE) - DNA adduct, a wide variety of non-bulky base damage and singlestrand breaks formed by free radicals during metabolic activation of PAHs are also involved in the PAH carcinogenesis (Frenkel, 1992; Bankson et al., 1993; Pryor, 1997). Consequently, genetic variation of an individual's ability to repair DNA base damage and single-strand breaks may confer differential risk for PAH-induced lung cancer. In humans, the base excision repair (BER) is responsible for the repair of oxidative DNA damage (Hoeijmakers, 2001). Since the chromosomal damage has been recognized as an important early biological event in chemical carcinogenesis, the relationship between genetic polymorphisms of BER proteins and $\mathrm{PAH}$-induced chromosomal damages is important for the understanding of PAH carcinogenesis.

The cytogenetic analysis of peripheral lymphocytes is a method traditionally used to evaluate occupational exposure to clastogens (Hungerford, 1965; Carrano \& Natarajan, 1982, Kalina et al., 1991). The study of cytogenetic endpoints in lymphocytes, such as structural chromosomal alteration (CA) and micronucleus (MN), which are biomarkers of early biological effects of exposure to genotoxic agents, is considered advisable in transitional studies of groups at risk of occupational cancer, together with the determination of indicators of exposure and of biologically effective doses (Aitio et al., 1988). The XRCC1 gene participates in the repair of mammalian DNA and plays an integral role in BER (Wood et al., 2001). A polymorphism at codon 399 of the XRCC1 gene results in an amino acid substitution from arginine to glutamine in the BRCA1 C terminus domain of the gene, a region required for the efficient

e-mail: Shanmugam Suresh Kumar: sureshbiogenetic@gmail. com; Vellingiri Balachandar: geneticbala@yahoo.co.in

Abbreviations: BER, Base Excision Repair; BPDE, benzo(a)pyrene diolepoxide; CA, chromosomal alteration; MN, micronucleus; PBLC, peripheral blood lymphocytes culture; OSHA, Occupational Safety and Health Administration; PAHs, polycyclic aromatic hydrocarbons. 
repair of single strand-breaks (Taylor et al., 2002). The functional significance of the XRCC1 Arg399Gln polymorphism has been evaluated in several studies (Ginsberg et al., 2011; Taylor et al., 2002; Matullo et al., 2001; Duell et al., 2000; Abdel-Rahman \& El-Zein, 2000; Lunn et al., 1999). The Gln allele variant was associated with an increased level of sister chromatid exchanges (SCEs) after exposure to the tobacco-specific nitrosamine, 4(methylnitrosoamino)-1-(3-pyridyl)-1-butanone (NNK) (Abdel-Rahman \& El-Zein, 2000). In addition, a higher level of SCEs and polyphenol DNA adducts were present in smokers' lymphocytes, homozygous for the 399 Gln allele (Duell et al., 2000). The present study aims to investigate the relationship between the exposure of PAHs and the risk of genetic damages, such as CA and $\mathrm{MN}$ in peripheral blood lymphocytes (PBLC) and gene polymorphism among smoking and non-smoking coke oven workers.

\section{MATERIALS AND METHODS}

Study area and subject recruitment. The study was carried out in 27 coke oven workers from a steel company in Coimbatore district, South India. The control group consisted of 27 healthy subjects selected based on the questionnaire that covered standard demographic questions (age, genetic disorders, number of X-ray diagnosis, vaccinations, medication, smoking, alcohol, etc.). The control group included healthy individuals selected from the same area, but who were not exposed to PAHs or any other chemicals and/or radiations. In our study, all the exposed subjects were selected from the top side, middle side, and bottom working areas of the coke oven plant. In addition, higher permissible exposure limit of PAHs was measured at the workplace which exceeds the exposure limit mentioned by the Occupational Safety and Health Administration (OSHA). The coke oven gas consists of $2 \%$ of $\mathrm{CO}_{2}, 5.5 \%$ of $\mathrm{CO}, 32 \%$ of $\mathrm{CH}_{4}$, $51.9 \%$ of $\mathrm{H}_{2}, 0.3 \%$ of $\mathrm{O}_{2}$, and $4.8 \%$ of $\mathrm{N}_{2}$. In our study the exposed subjects between 20 to 53 years of age employed in coke oven plant were recruited. The employment duration ranges from $0.5-13$ years; therefore, the groups were categorized based on the average age and exposure duration as group I $(<35$ yrs of age and $<12$ yrs of exposure) and group II ( $\geq 35$ yrs of age and $\geq 12$ yrs of exposure), respectively.

Sample Collection. At the time of blood collection $(3 \mathrm{ml} /$ individual) the workers signed a term of informed consent and replied to a standard questionnaire to de-

Table 1. General characteristics of coke oven workers and control subjects

\begin{tabular}{|c|c|c|c|}
\hline \multirow{2}{*}{ Characteristics } & \multicolumn{2}{|c|}{$\begin{array}{l}\text { Number of subjects } \\
n=54\end{array}$} & \multirow[t]{2}{*}{ Percentage (\%) } \\
\hline & Exposed subjects & Controls & \\
\hline Group I (<35 years) & 12 & 12 & $44.4 \%$ \\
\hline Group II $s$ ( $\geq 35$ years) & 15 & 15 & $55.5 \%$ \\
\hline \multicolumn{4}{|l|}{ Gender } \\
\hline Male & 27 & 27 & $100 \%$ \\
\hline \multicolumn{4}{|l|}{ Smoking } \\
\hline & 13 & 13 & $48.1 \%$ \\
\hline No & 14 & 14 & $51.8 \%$ \\
\hline \multicolumn{4}{|l|}{ Work duration } \\
\hline$<12$ years & 11 & NA & $40.7 \%$ \\
\hline$\geq 12$ years & 16 & NA & $59.2 \%$ \\
\hline
\end{tabular}

Refer to Table S1 for detailed raw data of Table 1. NA, Not applicable; Group I, ( $<35$ years), Group II ( $\geq 35$ years) termine the profile and habits (age, time of work, salary, type of diet most commonly practiced, type of housing, use of drugs and medications, etc.). The study was conducted with the approval of the Institutional Ethical Committee.

Chromosomal aberration (CA) assay. All chemical reagents were purchased from Sigma Chemicals (St. Louis, MO, USA), except for colcemid that was obtained from Gibco Laboratory (Grand Island, NY, USA). Upon arrival in the laboratory, blood samples were set up to establish cell cultures following standard procedures in the laboratory (Moorhead et al., 1960). Briefly, $0.5 \mathrm{ml}$ of whole blood was added to $4.5 \mathrm{ml}$ RPMI 1640 medium, supplemented with $10 \%$ fetal bovine serum, $2 \mathrm{mM} \mathrm{L-}$ glutamine, $1 \%$ streptomycin-penicillin antibiotics, 0.2 $\mathrm{ml}$ reagent grade phytohemagglutinin, and incubated at $37^{\circ} \mathrm{C}$. At $71 \mathrm{st} \mathrm{hr}$, cultures were treated with $0.1 \mu \mathrm{g} / \mathrm{ml}$ colcemid to block cells in mitosis.

Lymphocytes were harvested at $72 \mathrm{~h}$ by centrifuging cells to remove culture medium (800-1000 rpm/7 min), and adding hypotonic solution ( $\mathrm{KCl} 0.075 \mathrm{M}$ ) at $37^{\circ} \mathrm{C}$ for $20 \mathrm{~min}$ to induce cell swelling, following the treatment with fixative (3:1 ratio of methanol:acetic acid), which was then repeated. Cytological preparations were made by adding 2-3 drops of the concentrated cell suspension onto slides rinsed with ice-cold acetic acid $(60 \%)$. Slides were carefully dried on a hot plate $\left(56^{\circ} \mathrm{C}\right.$, 2 min). For CA analysis, 100 complete metaphase cells were evaluated per subject under a microscope $(100 \mathrm{x})$ to identify numerical and structural CA.

Micronucleus (MN) assay. The $\mathrm{MN}$ assay was performed using the cytochalasin B technique (Fenech \& Morley 1985). Lymphocytes were cultured as described above. Cytochalasin B $(6 \mu \mathrm{g} / \mathrm{ml})$ was added at $44 \mathrm{~h}$ of incubation. After a total incubation time of $72 \mathrm{~h}$ at $37^{\circ} \mathrm{C}$, the cells were harvested by centrifugation, rinsed, and submitted to mild hypotonic treatment followed by immediate fixation with methanol: acetic acid. Slides were prepared according to standard cytogenetic procedures and stained with $4 \%$ Giemsa. Slides were then coded and scored by light microscopy at 400x magnification. For each experiment, 1000 binucleated lymphocytes with well-preserved cytoplasm were scored. MN was identified according to the criteria of Fenech et al. (2003).

Genotypic analysis for XRCC1 $399 \mathrm{Arg} / \mathrm{Gln}$ polymorphism. The whole genomic DNA was collected as per kit protocol (Bangalore Genei-Frozen blood DNA extraction kit) for PCR analysis (Duell et al., 2000). Cleavage with polymorphism was carried out using MspI for Arg399Gln (Lei et al., 2002).

Statistical analysis. A parametric statistical test was carried out in the study. The statistical significance of the difference in the frequency of XRCC1 genotype between groups was calculated by $\mathrm{X}^{2}$ test. The analysis was performed using SPSS (version 13), and ultimately confirmed using ANOVA within and between the groups of exposed subjects and controls.

\section{RESULTS}

A total of 54 subjects, including 27 exposed and 27 controls, were recruited for our study. Their characteristics were listed in Table 1. The study includes group I 12 (44\%) subjects and group II $15(56 \%)$ for both exposed and controls, respectively, in which 13 (48\%) were smokers and $14(52 \%)$ were non-smok- 
Table 2. Description of chromosomal aberrations and Micronucleus in coke oven workers in comparison with unexposed controls

\begin{tabular}{|c|c|c|c|c|c|c|}
\hline \multirow{2}{*}{ Group } & \multirow{2}{*}{ Age } & \multirow{2}{*}{ Work duration } & \multicolumn{2}{|l|}{ CA/100 cells } & \multirow{2}{*}{ Total } & \multirow{2}{*}{ MN/1 000 cells } \\
\hline & & & CTAs & CSAs & & \\
\hline $\begin{array}{l}\text { Coke oven workers } \\
\text { Group I ( }<35 \text { years) } \\
\text { Group II ( } \geq 35 \text { years) }\end{array}$ & $\begin{array}{l}27.9 \pm 3.9 \\
44.4 \pm 5.8\end{array}$ & $\begin{array}{l}5.5 \pm 3.5 \\
18.2 \pm 4.5\end{array}$ & $\begin{array}{l}1.7 \pm 1.0^{*} \\
3.4 \pm 1.0^{*}\end{array}$ & $\begin{array}{l}0.25 \pm 0.4^{*} \\
0.46 \pm 0.5\end{array}$ & $\begin{array}{l}2 \pm 1.2^{*} \\
4.6 \pm 1.4^{*}\end{array}$ & $\begin{array}{l}1.9 \pm 2.7^{*} \\
6.6 \pm 2.2^{*}\end{array}$ \\
\hline $\begin{array}{l}\text { Controls } \\
\text { Group I ( }<35 \text { years) } \\
\text { Group II ( } \geq 35 \text { years) }\end{array}$ & $\begin{array}{l}27.5 \pm 4.4 \\
43.5 \pm 5.2\end{array}$ & $\begin{array}{l}\text { NA } \\
\text { NA }\end{array}$ & $\begin{array}{l}0.33 \pm 0.65 \\
1.26 \pm 0.79^{*}\end{array}$ & $\begin{array}{l}0.16 \pm 0.38 \\
0.6 \pm 0.50\end{array}$ & $\begin{array}{l}0.5 \pm 0.6 \\
1.8 \pm 0.9\end{array}$ & $\begin{array}{l}1.0 \pm 0.9 \\
2.8 \pm 1.3^{*}\end{array}$ \\
\hline $\begin{array}{l}\text { Coke oven Workers } \\
\text { Smokes } \\
\text { Non smokers }\end{array}$ & $\begin{array}{l}29.5 \pm 5.3 \\
45.2 \pm 5.9\end{array}$ & $\begin{array}{l}18.9 \pm 4.4 \\
6.6 \pm 4.3\end{array}$ & $\begin{array}{l}3.4 \pm 1.1 \\
1.7 \pm 1.0\end{array}$ & $\begin{array}{l}1.4 \pm 0.6 \\
0.5 \pm 0.6\end{array}$ & $\begin{array}{l}4.9 \pm 1.7 \\
2.3 \pm 1.1\end{array}$ & $\begin{array}{l}6.6 \pm 2.6 \\
3.3 \pm 2.1\end{array}$ \\
\hline $\begin{array}{l}\text { Controls } \\
\text { Smokes } \\
\text { Non smokers }\end{array}$ & $\begin{array}{l}29.2 \pm 5.7 \\
44.1 \pm 5.6\end{array}$ & $\begin{array}{l}\text { NA } \\
\text { NA }\end{array}$ & $\begin{array}{l}1.30 \pm 0.8 \\
0.42 \pm 0.6\end{array}$ & $\begin{array}{l}0.5 \pm 0.5 \\
0.2 \pm 0.4\end{array}$ & $\begin{array}{l}1.7 \pm 1.0 \\
0.7 \pm 0.7\end{array}$ & $\begin{array}{l}3 \pm 1.3 \\
1.1 \pm 0.9\end{array}$ \\
\hline
\end{tabular}

*values significant at $\mathrm{p}<0.05$ level by ANOVA; Refer to Table S1 for detailed raw data of Table 2; CTAs, chromatid type aberration; CSAs, chromosomal type aberrations; MN, Micronucleus; Group I (<35 years), Group II ( $\geq 35$ years); NA, Not applicable. *Work duration $<12$ year / $\geq 12$ year.

ers. The exposed subjects and controls were matched for gender $(100 \%$ males $)$ and age $( \pm 2$ years relaxed). In our study, significant increase in CA and MN frequencies were observed in exposed subjects employed for a long time (group II — 18.2 \pm 4.5 ) when compared to short duration workers (group I $-5.5 \pm 3.5$ ). Table 2 shows higher frequency of total CA in exposed subjects (4.6 \pm 1.4$)$ compared to controls $(1.8 \pm 0.9)$; similarly, the MN frequency was higher in exposed subjects $(6.6 \pm 2.2)$ compared to controls $(2.8 \pm 1.3)$. Statistically significant results were obtained for both $\mathrm{CA}$ and $\mathrm{MN}$ in exposed subjects, compared to controls (ANOVA). A higher degree of MN frequency was observed in smokers (coke oven workers) (6.6 \pm 2.6$)$ compared to nonsmokers $(3.3 \pm 2.1)$. Also, the $\mathrm{MN}$ frequency in smokers was significant $(3 \pm 1.3)$ when compared to non-smoking $(1.1 \pm 0.9)$ exposed subjects. Table 3 shows allele frequencies of XRCC1 399Gln polymorphism of both exposed and control subjects, with insignificant results in exposed (0.320) and control subjects (0.381). XRCC1 is involved in the efficient repair of DNA single stand breaks. Regression analysis was carried out in XRCC1 $399 \mathrm{Gln}$ frequency in coke oven workers and the results were tabulated.

\section{DISCUSSION}

PAHs have been identified as a major source of carcinogenic risk among coke oven workers (IARC, 1987). Exposure to high concentrations of PAHs in the environment and tobacco smokers have elevated levels of aromatic DNA adducts in blood cells (Eder, 1999). Chromosome defects are recognized as being the basis of a number of human genetic diseases. The frequency of CA in peripheral blood lymphocytes is a relevant biomarker for cancer risk in humans, reflecting either early biological effects of genotoxic carcinogens or individual cancer susceptibility (Heussner et al., 1985). Our findings support these earlier studies, as they include higher values in the exposed subjects.

According to Bloomfield (Bloomfield et al., 1987), there is a positive correlation between CA frequency and increased cancer risk. Many investigators showed that the frequency of CAs in PBLs is a relevant biomarker for cancer risk in humans (Hagmar et al., 1998). According to Agova et al. (2005), most commonly detected abnormalities were gaps and breaks, which are increased in the coke oven workers. The main relevance of lymphocyte chromosome damage is its indicative value for genotoxic exposure, which is considered to be related with the multistage process of carcinogenesis (Hartmann, 1983; Hagmar et al., 1994; Smerhovsky et al., 2001; Norppa et al., 2006). Several studies have reported the relationship between aging and structural CA. The CAs in controls might be due to factors like age and lifestyle. Some studies have found a significant influence of age on CA frequency (Ramsey et al., 1995; Tucker \& Moore, 1996). The control subjects of group I and II showed minimum number of CA when compared to the exposed subjects. An age-related increase in the aneuploid cells of human lymphocytes has been reported in a number of studies (Nowinski et al., 1990). Moreover, the results of the present study also points out the role of age in CA, which was supported by the study of Balachandar and coworkers (Balachandar et al., 2008). Our study reveals that increase in age; both in exposed and control group shave significantly higher total CA.

MN assay in lymphocytes was suitable to detect the PAHs induced chromosome damage in coke oven workers exposed to high levels of PAHs (Burgaz et al., 1995; Bonassi et al., 2001; Leng et al., 2004). According to Pa-

Table 3. XRCC1 genotypes and allele frequencies in coke oven workers and controls

\begin{tabular}{|c|c|c|c|c|c|c|}
\hline \multirow{2}{*}{ XRCC1 399} & \multirow{2}{*}{$\begin{array}{l}\text { Total number } \\
\text { of samples }\end{array}$} & \multirow{2}{*}{$\mathrm{Arg} / \mathrm{Gln}$} & \multirow{2}{*}{$\begin{array}{l}\text { 399GIn } \\
\text { frequency }\end{array}$} & \multicolumn{3}{|c|}{ Regression analysis } \\
\hline & & & & Slope(b) & $y$-Intercept(a) & Regression equation(y) \\
\hline Coke oven workers & 27 & $\begin{array}{l}58(53.70 \%) \\
p=1.000 \\
O R=1 \\
95 \% \\
C l=0.564-1.773\end{array}$ & 0.320 & 0.814 & -0.094 & $-0.094+0.815$ \\
\hline Controls & 27 & 50 (46.29\%) & 0.381 & 0.774 & -0.084 & $-0.084+0.775$ \\
\hline
\end{tabular}

$\mathrm{Cl}$, confidence interval; OR, odd ratio; XRCC 1, X-ray cross complementation gene 1; Gln, glycine; Arg, arginine; p, probability 
Table 4. Pearson's correlation analysis of coke oven exposure to PAHs, age, and smoking habit with the levels of CA and MN

\begin{tabular}{|c|c|c|c|c|c|c|}
\hline & & Group 1 or 2 & Smoking habits & $\begin{array}{l}\text { Chromatid type } \\
\text { alterations }\end{array}$ & $\begin{array}{l}\text { Chromosomal } \\
\text { type alterations }\end{array}$ & $\begin{array}{l}\text { Micronucleus } \\
\text { changes }\end{array}$ \\
\hline \multirow{3}{*}{ Group 1 or 2} & Pearson Correlation & 1 & $.713^{* *}$ & $.660^{* *}$ & $.678^{* *}$ & $.688^{* *}$ \\
\hline & Sig. (2-tailed) & & .000 & .000 & .000 & .000 \\
\hline & $\mathrm{N}$ & 27 & 27 & 27 & 27 & 27 \\
\hline \multirow{3}{*}{ Smoking habits } & Pearson Correlation & $.713^{* *}$ & 1 & $.612^{* *}$ & $.578^{* *}$ & $.576^{* *}$ \\
\hline & Sig. (2-tailed) & .000 & & .001 & .002 & .002 \\
\hline & $\mathrm{N}$ & 27 & 27 & 27 & 27 & 27 \\
\hline \multirow{3}{*}{$\begin{array}{l}\text { Chromatid type alte- } \\
\text { rations }\end{array}$} & Pearson Correlation & $.660^{* *}$ & $.612^{* *}$ & 1 & $.598^{* *}$ & $.931^{* *}$ \\
\hline & Sig. (2-tailed) & .000 & .001 & & .001 & .000 \\
\hline & $\mathrm{N}$ & 27 & 27 & 27 & 27 & 27 \\
\hline \multirow{3}{*}{$\begin{array}{l}\text { Chromosomal type } \\
\text { alterations }\end{array}$} & Pearson Correlation & $.678^{* *}$ & $.578^{* *}$ & $.598^{* *}$ & 1 & $.698^{* *}$ \\
\hline & Sig. (2-tailed) & .000 & .002 & .001 & & .000 \\
\hline & $\mathrm{N}$ & 27 & 27 & 27 & 27 & 27 \\
\hline \multirow{3}{*}{ Micronucleus changes } & Pearson Correlation & $.688^{* *}$ & $.576^{* *}$ & $.931^{* *}$ & $.698^{* *}$ & 1 \\
\hline & Sig. (2-tailed) & .000 & .002 & .000 & .000 & \\
\hline & $\mathrm{N}$ & 27 & 27 & 27 & 27 & 27 \\
\hline
\end{tabular}

**Significant at 0.01 level (2-tailed)

vanello et al. (2008), coke oven workers who were heavily exposed to PAHs $(80 \%$ of workers exceeded the urinary 1-pyrenol biological exposure index value) presented significantly higher MN frequency in PBLs relative to control subjects. Our study supports the above findings by showing higher $\mathrm{MN}$ frequency in smokers of group II exposed subjects, which depicts a significant result. According to several investigations (Carrano \& Natarajan 1982; Motykiewicz et al., 1992; Bender et al., 1992; Buchet et al., 1995; Judson \& Stephens, 2001; Bindhya et al., 2010), XRCC1 399Arg/Gln polymorphism does not alter the affinity of XRCC1 for polynucleotide kinase/ phosphatasepoly ADP-ribose polymerase among PAHs exposed workers. Our study highlights that there was no relationship between coke oven exposure and XRCC1 $399 \mathrm{Arg} / \mathrm{Gln}$ polymorphism. Leng et al. (2005) reported a statistically non-significant additive interaction between the XRCC1 399GIn allele and PAHDNA adducts as XRCC1 genotypes. The result shows that CA, MN, and PCR-RFLP were found to be sensitive biomarkers in detecting the effect of exposure to PAHs.

Individuals with occupational exposure to toxic substances such as PAHs were given priority for investigation. The present study demonstrates that exposure to coke oven emissions constitutes an increased carcinogenic risk and confirmed that applied cytogenetic markers constitute a useful tool for determination of these risks. Thus our findings indicates that, the exposed smokers in coke oven industry and slow acetylators were more prone to genetic damage. It was concluded that coke oven workers at risk should be carefully monitored snd should take adequate protective measures to prevent long-term adverse effects. We found that, coke oven workers, occupationally exposed to PAHs, shows significantly increased levels of biomarkers, especially CA and MN, which were found to be more sensitive for biomonitoring the PAHs exposure at occupational settings.

\section{Acknowledgments}

The authors would like to thank the authorities of the Bharathiar University, India for providing infrastructure facilities necessary for conducting this research and the subjects who volunteered to take part in this study. Part of the research work was supported by the $2012 \mathrm{KU}$ Brain Pool of Konkuk University.

\section{REFERENCES}

Armstrong B, Hutchinson E, Unwin J, Fletcher T (2004) Lung cancer risk after exposure to polycyclic aromatic hydrocarbonsa review and meta-analysis. Environ Health Perspect 112: 970-978.

Abdel-Rahman S, El-Zein R (2000) The 399 Gln polymorphism in the DNA repair gene XRCC1 modulates the genotoxic response induced in human lymphocytes by the tobacco specific nitrosamine NNK. Cancer Lett 159: 63-71.

Agova S, Groseva D, Panev, T Popov T, Toncheva D, Hadjidekova $\mathrm{V}$ (2005) Effect of environmental exposure to PAHs on somatic chromosomes. Turk J Med Sci 35: 143-148.

Aitio A, Becking G, Berlin A, Bernard A, Foa V, Kello D, Krug E, Léonard A, Nordberg G (1988) Indicators for assessing exposure and biological effects of genotoxic chemicals, Consensus and Technical Reports, EUR 1164Z! EN, CEC, Luxembourg.

Balachandar V, Lakshmankumar B, Suresh K, Sasikala K (2008) Evaluation of chromosome aberrations in subjects exposed to environmental tobacco smoke in Tamilnadu, India. Bull Environ Contam Toxicol 81: 270-276.

Bankson DD, Kestin M, Rifai N (1993) Role of free radicals in cancer and atherosclerosis. Clin Lab Med 13: 463-80.

Bender MA, Leonard RC, White JO, Costantino JP, Redmond CK (1992) Chromosomal aberration and sister-chromatid ex-changes in lymphocytes from coke oven workers. Mutat Res 206: 11-16.

Bindhya S, Balachandar V, Sudha S, Mohana devi S, Varsha P, Kandasamy K, Gnana prakash V, Sasikala K (2010) Assessment of occupational cytogenetic risk, among petrol station workers. Bull Environ Contam Toxicol 85: 121-124.

Bloomfield DC, Frent JM, Van Den Berghe D (1987) Report of the committee on structural chromosomal changes in neoplasia, human gene mapping 9: ninth international workshop on human gene mapping 9. Cytogenet Cell Genet 46: 344-46.

Bonassi S, Fenech M, Lando C (2001) Human micronucleus project: international database comparison for results with the cytokinesisblock micronucleus assay in human lymphocytes: I. Effect of laboratory protocol, scoring criteria, and host factors on the frequency of micronuclei. Environ Mol Mutagen 37: 31-45. 
Buchet JP, Ferreira M, Burrion JB, Leroy T, Kirsch-Volders M, Van Hummelen P, Jacques J, Cupers L, Delavignette JP, Lauwerys R (1995) Tumor markers in serum, polyamines and modified nucleosides in urine, and cytogenetic aberrations in lymphocytes of workers exposed to polycyclic aromatic hydrocarbons. Am J Industrial Med 27: 523-543.

Burgaz S, Iscan A, Buyukbingol ZK, Bozkurt A, Karakaya AE (1995) Evaluation of micronuclei in exfoliated urothelial cells and urinary thioether excretion of smokers. Mutat Res 335: 163-169.

Carrano AV, Natarajan AT (1982) Considerations for population monitoring using cytogenetic techniques. Mutat Res 204: 379-406.

Chen B, Hu Y, Jin T, Lu D, Shao M, Zheng L, Wang Q, Shen Y, Liu H, Liu Y, Zhou Y (2007) The influence of metabolic gene polymorphisms on urinary 1 hydroxypyrene concentrations in Chinese coke oven workers. Science Total Environ 38: 38-46.

Chen ML, Mao IF, Wu MT, Chen JR, Ho CK, Smith TJ, Wypij D, Christiani DC (1999) Assessment of coke oven emissions exposure among coking workers. Am Ind Hyg Assoc J 60: 105-110.

Clonfero E, Granella M, Marchioro M, Leopardi Barra E, Nardini B, Ferri GM, Foa AV (1995) Urinary excretion of mutagens in coke oven workers. Carcinogenesis 16: 547-554.

Dipple A, Moschel RC, Bigger CAH (1984) Polynuclear aro- matic hydrocarbons. In Chemical carcinogens, Searle CE, ed. Am Chem Soc 1: $141-163$.

Duell EJ, Wiencke JK, Cheng TJ, Varkonyi A, Zuo ZF, Ashok TDS, Mark EJ, Wain JC, Christiani DC, Kelsey KT (2000) Polymorphisms in the DNA repair genes XRCC1 and ERCC2 and biomarkers of DNA damage in human blood mononuclear cells. Carcinogenesis 21: 965-971.

Eder E (1999) Intraindividual variations of DNA adduct levels in humans. Mutat Res 424: 249-261.

Fenech M, Morley AA (1985) Measurement of micronuclei in lymphocytes. Mutat Res 147: 29-36.

Fenech M, Chang WP, Kirsch-Volders M, Holland N, Bonassi S, Zeiger E (2003) HUMN project: detailed description of the scoring criteria for the cytokinesis-block micronucleus assay using isolated human lymphocyte cultures. Mutat Res 534: 65-75.

Frenkel K (1992) Carcinogen-mediated oxidant formation and oxidative DNA damage. Pharmacol Ther 53: 127-66.

Ginsberg G, Angle K, Guyton K, Sonawane B (2011) Polymorphism in the DNA repair enzyme XRCC1: Utility of current database and implications for human health risk assessment. Mutat Res 727: 1-15.

Hagmar L, Bonassi S, Stromberg U (1998) chromosomal aberrations in lymphocytes predict human cancer: a report from the european study group on cytogenetic biomarkers and health. Cancer Res 58: 4117-4121.

Hagmar L, Brogger A, Hansteen LL, Heim S, Hogstedt B, Knudsen L, Lambert B, Linnainmaa K, Mitelman F, Nordenson I, Reuterwall C, Salomaa S, Skerfing S, Sorsa M (1994) Cancer risk in humans predicted by increased levels of chromosomal aberrations in lymphocytes: Nordic study group on health risk of chromosome damage. Cancer Res 54: 2919-2922.

Hartmann PE (1983) Mutagens: some possible health impacts beyond carcinogenesis. Envi Mutat 5: 139-152.

Hemminki K, Grzybowska E, Chorazy M, Twardowska-Sancha K, Sroczyniki SW, Putnam KL, Randerath K, Phillips DH, Hewer A, Santella RM, Young TL, Perera FP (1990) DNA adducts in humans environmentally exposed to aromatic compounds in an industrial area of Poland. Carcinogenesis 11: 1229-1231.

Heussner JC, Ward JB, Legator MS (1985) Genetic monitoring of aluminium workers exposed to coal tar pitch volatiles. Mutat Res 155: $143-155$.

Hungerford DA (1965) Leucocytes cultures from small inocula of whole blood and preparation of metaphase chromosomes by treatment with hypotonic KCl. Stain Technol 40: 333-338.

Hoeijmakers JH (2001) Genome maintenance mechanisms for preventing cancer. Nature 411: 366-74.

IARC (1983) Monographs on the evaluation of the carcinogenic risk to bumans, vol 32, pp 95-451. International Agency on Cancer Research, Lyon, France.

IARC (1984) Monographs on the evaluation of the carcinogenic risk of chemicals to humans: Vol. 34, pp 101-131, Polynuclear Aromatic Compounds, Part 3, International Agency on Cancer Research, Lyon,

IARC (1987) Monographs on the evaluation of carcinogenic risk to humans. Overall evaluation of carcinogeneity: an updating of International Agency on Cancer Research. Monographs 42: 176-178.

IARC (2010) some non-heterocyclic polycyclic aromatic hydrocarbons and some related exposures, International Agency on Cancer Research. Monographs Eval Carcinog Risks Hum 92: 1-853.
Judson R, Stephens JC (2001) Notes from the SNP vs. haplotype front. Pharmacogenomics 2: 7-10.

Kalina I, Sram JR, Konecna H, Ondrussekova A (1991) Cytogenetic analysis of peripheral blood lymphocytes in workers occupationally exposed to polychlorinated biphenyls, Terato-gen Carcinogen. $M u$ tagen 11: 77-82.

Kuljukka-Rabb T, Nylund L, Vaaranrinta R, Savela K, Mutanen P, Veidebaum T, Sorsa M, Rannug A, Peltonen K (2002) The effect of relevant genotypes on PAH exposure-related biomarkers. I Exposure Anal Environ Epidem 12: 81-91.

Lei YC, Hwang SJ, Chang CC, Kuo HW, Luo JC, Chang MJ, Cheng TJ (2002) Effects on sister chromatid exchange frequency of polymorphisms in DNA repair gene XRCC1 in smokers. Mutat Res 519: 93-101.

Leng S, Dai Y, Niu Y (2004) Effects of genetic polymorphisms of metabolic enzymes on cytokinesis-block micronucleus in peripheral blood lymphocyte among coke-oven workers. Cancer Epidemiol Biomarkers Prev 13: 631-639.

Leng S, Cheng J, Zhang L (2005) The Association of XRCC1 haplotypes and chromosomal Damage Levels in Peripheral Blood Lymphocyte among Coke-Oven Workers. Cancer Epidemiol Biomarkers Prev 14: 1295-1301.

Lunn R, Langlois R, Hsieh L, Thompson C, Bell D (1999) XRCC1 polymorphisms: effects on aflatoxin B1-DNA adducts and glycophorin A variant frequency. Cancer Res 59: 2557-2561.

Marczynski B, Preuss R, Mensing T, Angerer J, Seidel A, El Mourabit A, Wilhelm M, Bruning T (2005) Genotoxic risk assessment in white blood cells of occupationally exposed workers before and after alteration of the polycyclic aromatic hydrocarbon $(\mathrm{PAH})$ profile in the production material: comparison with $\mathrm{PAH}$ air and urinary metabolite levels. Int Arch Occup Environ Health 78: 97-108.

Matullo G, Palli D, Peluso M, Guarrera S, Carturan S, Celentano E, Krogh V, Munnia A, Tumino R, Polidoro S, Piazza A Vineis P (2001) XRCC1, XRCC3, XPD gene polymorphisms, smoking and 32 P-DNA adducts in a sample of healthy subjects. Carcinogenesis 22: 1437-1445.

Moorhead PS, Novell PC, Mellman WJ, Battips DM, Hungerford DA (1960) Chromosome preparation of leukocyte culture from peripheral blood. Exp Cell Res 20: 613-615.

Motykiewicz Cl, Michalska J, Pendzich J (1992) A cytogenetic study of men environmentally and occupationally exposed to airborne pollutants. Mutat Res 280: 253-259.

Norppa H, Bonassi S, Hansteen IL (2006) Chromosomal aberrations and SCEs as biomarkers of cancer risk. Mutat Res 600: 37-45.

Nowinski GP, Van Dyke DL, Tilley BC, Jacobsen G, Babu VR, Worsham MJ, Wilson GN, Weiss L (1990) The frequency of aneupboidy in cultured lymphocytes is correlated with age and gender but not with reproductive history. Am J Hum Genet 46: 11011111.

Pavanello S, Kapka L, Siwinska E, Mielzyñska D, Bolognesi C, Clonfero $E$ (2008) Micronuclei related to anti-B[a] PDE-DNA adduct in peripheral blood lymphocytes of heavily polycyclic aromatic hydrocarbon-exposed nonsmoking coke-oven workers and controls. Cancer Epidemiol Biomarkers Prev 17: 2795-2799.

Perera FP (1997) Environment and cancer: who are susceptible? Science 278: 1068-1073.

Pryor WA (1997) Cigarette smoke radicals and the role of free radicals in chemical carcinogenicity. Environ Health Perspect 105: 875-882.

Ramsey MJ, Moore DH, Briner JF, Lee DA, Olsen LA, Senft JR, Tucker JD (1995) The effects of age and lifestyle factors on the accumulation of cytogenetic damage as measured by chromosome painting. Mutat Res 338: 95-106.

Smerhovsky Z, Landa K, Rossner P (2001) Risk of cancer in an occupationally exposed cohort with increased level of chromosomal aberrations. Environ Health Perspect 109: 41-45.

Taylor RM, Thistlethwaite A, Caldecott KW (2002) Central role for the XRCC1 BRCT I domain in mammalian DNA single-stranded break repair. Mol Cell Biol 22: 2556-2563.

Tucker JD, Moore DH (1996) The importance of age and smoking in evaluating adverse cytogenetic effects of exposure to environmental agents. Environ Health Perspect 104: 489-492.

Wood RD, Mitchell M, Sgouros J, Lindahl T (2001) Human DNA repair genes. Science 291: 1284-1289.

Wu MT, Mao IF, Ho CK, Wypij D, Lu PL, Smith TJ, Chen ML, Christiani DC (1998) Urinary 1-hydroxypyrene concentrations in coke oven workers. Occup Environ Med 55: 461-467.

Yang HH, Lai SO, Hsieh LT, Hsueh HJ, Chi TW (2002) Profiles of PAH emission from steel and iron industries. Chemosphere 48: 10611074. 